\title{
Courts as Organizations: Governance and Legitimacy
}

Tomas Aquino Guimaraes ${ }^{1}$ Edson Ronaldo Guarido Filho, ${ }^{2,3}$ Bruno Batista de Carvalho Luz ${ }^{1}$

\footnotetext{
${ }^{1}$ Universidade de Brasília, Brasília, DF, Brazil

${ }^{2}$ Universidade Positivo, Curitiba, PR, Brazil

${ }^{3}$ Universidade Federal do Paraná, Curitiba, PR, Brazil
}

Received 05 May 2020. This paper was with the authors for two revisions. Accepted 10 March 2021.

First published online 19 March 2021.

Editor-in-chief: Carlo Gabriel Porto Bellini (D) (Universidade Federal da Paraíba, João Pessoa, PB, Brazil)

Associate editor: Jorge Carneiro (D) (Fundação Getulio Vargas, EAESP, São Paulo, SP, Brazil)

Reviewers: Ivan Beck Ckagnazaroff (D) (Universidade Federal de Minas Gerais, FACE, Belo Horizonte, MG, Brazil) and one anonymous reviewer

Editorial assistants: Kler Godoy and Simone Rafael (ANPAD, Maringá, PR, Brazil) 


\section{ABSTRACT}

The interdependence between governance and legitimacy of the courts is a subject that has not been much studied by scholars, especially those from the fields of public administration and organizational studies. Taking into account the importance of these topics for the functioning of these organizations, the purpose of this essay is twofold: to enrich the debate on the contribution of good governance to the legitimacy of courts, and to encourage researchers to address these themes in greater depth. To this end, the main literature on governance and legitimacy of courts is analyzed. Theoretical approaches contribute to the discussion of the functioning of courts, which are highly institutionalized organizations that depend heavily on a presumption of legitimacy. Ensuring this legitimacy has been one of the challenges for these organizations, which are required to adopt governance models that contribute to better management and performance. We argue that there are managerial and substantive implications for society, since the governance and legitimacy of courts can affect the system of justice. We put forward some propositions on the influence of judicial governance on the legitimacy of the justice system and on the perception of legitimacy of the courts. These propositions provide insights for a research agenda on these issues.

Keywords: legitimacy; governance; courts; administration of justice

JEL code: P37, P48 


\section{INTRODUCTION}

The progressive emergence of social, political, and economic factors that frame the justice system as a space beyond the judiciary has increased pressure on courts to improve the efficiency, quality, and social distribution of justice. These efforts are related to mechanisms of public governance and are not limited to service delivery, but include the impact on society (Almquist, Grossi, Helden, \& Reichard, 2013). We argue that judicial governance refers to practices and structures related to responsibilities and accountability, as well as acting in the public interest. In this sense, it is important to embrace governance and legitimacy in the same debate.

Judicial decisions intervene in social relations in democratic societies. On the one hand, courts play an important role, and it needs to be recognized that "courts are governmental institutions and that judges are agents of society" (Garoupa \& Ginsburg, 2015, p. 2). On the other hand, courts are subject to criticism, when, for example, they act as protagonists in promoting policies, as the Brazilian Supreme Court has on issues of political, health, scientific, social, and economic affairs. This has been described as supremocracy, where the Supreme Court exercises power over lower courts, to the detriment of the other powers of the republic (Brigida \& Verbicaro, 2020; Vieira, 2017).

The U.S. Supreme Court is usually seen as a political institution, in a pejorative sense, populated by liberal or conservative coalitions and, consequently, ideologically motivated, and subject to political manipulation (Fallon, 2018; Ramseyer, 1994). As Fallon (2018) says, "the people with the deepest, most corrosive cynicism about law and legitimacy of the Supreme Court are often those who began with the unrealistic expectation that the Justices' decision-making could be wholly apolitical or untouched by ideological influence" (Fallon, 2018, p. xi). At the end of 2020, the presidential nomination of a conservative justice, following the death of Justice Ginsburg, a liberal icon, restarted the debate on reshaping the political-ideological balance of the U.S. Supreme Court, including advocacy movements for expanding the size of the court.

The ultimate goal of courts is to maintain social balance and peace in social relations. They are, therefore, organizations whose legitimacy is taken for granted, or whose legitimacy is inherent in the existence of the organization. According to Gibson and Caldeira (1995), courts work under a "presumption of legitimacy" (Gibson \& Caldeira, 1995, p. 464), and "legitimacy provides courts authority; it allows them the latitude necessary to make decisions contrary to the perceived immediate interests of their constituents" (Gibson \& Caldeira, 1995, p. 460). Guimarães, Gomes, and Guarido (2018) suggest that most justice organizations, "especially the courts, police, and prisons, are highly institutionalized and legitimated in the sense that their existence and functioning are taken for granted" (Guimarães, Gomes, \& Guarido, 2018, p. 478).

This does not mean that legitimacy of courts is not contested, or that these organizations do not act to defend their own legitimacy. There are efforts in different countries to increase the efficiency and quality of justice, which may contribute to the legitimacy of the courts. The creation of the European Commission for the Efficiency of Justice (CEPEJ) and the International Consortium for Court Excellence (ICCE) are examples of efforts along these lines. The Brazilian

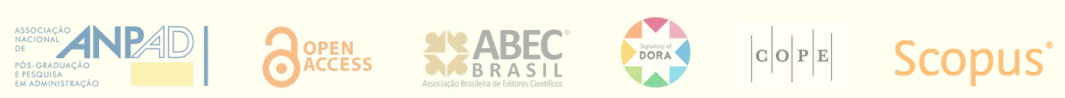


Judiciary, especially the higher courts, has adopted strategies to increase their visibility and, consequently, create closer ties with society. Judges have given interviews to the media, contradicting the principle that 'judges must only manifest themselves in the case file'; judgments have been broadcast live on TV and social media; the Brazilian National Council of Justice releases performance data from the country's courts. These are indications of concern over the visibility, accountability, and legitimacy of the justice system.

Legitimacy can also be conceived as a survival mechanism for courts, which need to be seen as "legitimate organizations" (Vergne, 2011, pp. 484-485) whose "existence, values, and behavior" (Vergne, 2011, pp. 484-485) are interpreted as congruent with social institutions, such as socially accepted rules, laws, and other patterns of conduct (Clayton, 1999; Gillman, 1999). The premise of legitimacy in different facets underpins an open discussion on the adoption of governance practices, as strategies for managing the legitimacy of the courts.

This essay discusses how governance can contribute to explain the legitimacy of courts, suggesting an agenda for analyzing this relationship. Firstly, without the ambition to be exhaustive, we conceptualize governance and legitimacy in the context of courts. Secondly, we advance propositions that intersect both themes. The importance of this article lies in the discussion of two organizational variables - governance and legitimacy - applied to courts, from the perspective of a recursive relationship. Few articles have addressed these two topics together. A search of the Scopus database on February 7, 2021, with the search key Title-Abs-Key ((governance $\mathrm{w} / 8$ court $^{*}$ ) and (legitimacy w/8 court $\left.^{*}\right)$ ) identified only five articles, of which one (Reinold, 2019) seemed relevant to the purpose of this essay. However, that article addresses the two issues superficially.

\section{GOVERNANCE IN THE CONTEXT OF COURTS}

The concept of governance is addressed in different fields, such as economics, political science, international relations, and law. A common basis in these conceptions is a decision-making process that seeks to serve the interests of several stakeholders. Insofar as governance seeks to reconcile interests, the concept incorporates a positive sense of 'good governance.' An in-depth analysis of this theme goes beyond the scope of this essay and a review of governance from different theoretical perspectives can be found in Ciacchi (2014).

The term 'governance' was popularized in the second half of the $20^{\text {th }}$ century in the administration and economics literature. Corporate governance was initially related to companies' best managerial practices. Later perspectives associated it with lower capital costs and more significant returns in terms of equity, efficiency, and more favorable treatment for stakeholders (Claessens, 2006). Corporate governance refers to the management of relationships between the company and its stakeholders, such as employees, customers, suppliers, and the government, aiming to mitigate and resolve conflicts between the interests of these parties. It is important to explore the concept of good governance applied to public administration and courts.

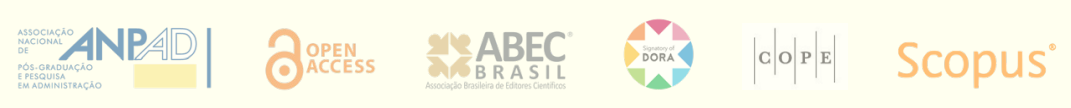


Broadly speaking, the governance of public administration involves the relationship between the state and society and focuses on the mode of governing. Governance, when associated with good public governance, presupposes a relationship model that favors a move from a hierarchical to a more cooperative model of governing, which may include several stakeholders, state and nonstate, and aim to "strike a balance between public power and civil society" (Buta, Guimarães, \& Akutsu, 2020, p. 2).

However, if the concept of public governance includes the participation of stakeholders in the decision-making process and in the provision of public services, it cannot be transferred directly to the courts. The literature covers various concerns around courts and their public (Bybee $\&$ Narasimhan, 2015; Epstein \& Knight, 2004). Courts work to solve conflicts, interpreting and enforcing laws - and generally solving a conflict does not serve the interests of all parties involved. "Everyone has a stake" (Fallon, 2018, p. x).

Courts deal with multiple stakeholders, both internal, like judges, and external, like the parties to the dispute, the executive and legislative branches, lawyers, and public prosecutors. All of them have diffuse and generally divergent interests. Moreover, courts have the power of self-control, which makes it difficult to identify who controls the judges. This all makes the governance of courts a multifaceted and complex issue to be analyzed. In fact, it can be said that the set of court stakeholders is society as a whole.

Therefore, judicial governance needs to be understood from its own characteristics, different from those that apply enterprises and public administration in general, or even as a "tool for the democratization of the judiciary" (Tavares \& Barbosa, 2016, p. 45). Emerging efforts on the topic in the field of management were summarized by Akutsu and Guimarães (2015) who suggested five dimensions of judicial governance: judicial performance; judicial independence; accountability and strategic resources of the judiciary; accessibility to justice; and structure of the judiciary. These authors also propose three levels of analysis to study judicial governance: institutional, organizational, and individual, with the goal of improving performance standards (Akutsu \& Guimarães, 2015). Their approach to judicial governance makes important points. First, the multidimensional perspective stratifies the representation of governance in the sphere of justice organizations. Second, the three-level governance approach highlights practices as key elements for connecting organizational behavior to the formal rules of the institutional environment.

There is little scientific literature on judicial governance, and the concept is generally characterized as part of court administration and evaluation models. The International Consortium for Court Excellence, for example, maintains the International Framework for Court Excellence, a quality management system designed to help courts improve their performance, in which governance is one of the dimensions of court administration (International Consortium for Court Excellence [ICCE], 2020). 


\section{LEGITIMACY IN THE CONTEXT OF COURTS}

Legitimacy is a concept that captures the relationship between authority and consent (Selznick, 1992). Deference to authority, whether to a court, a rule, or a position, presumes consent, which means it is based on the idea of rightfulness - a "recognized claim of right" - that supports deference (Selznick, 1992, p. 266). As a consequence, courts or any other institution are subject to social acceptance of their authority; they are not inherently legitimate or illegitimate (Friedman, 2016; Selznick, 1992).

In the organizational literature, under the tradition of sociological institutionalism, organizational legitimacy is a leading concept usually defined as "generalized perception or assumption that the actions of an entity are desirable, proper, or appropriate within some socially constructed system of norms, values, beliefs, and definitions" (Suchman, 1995, p. 574). Legitimacy links organizations and existing social parameters (Berger, Ridgeway, Fisek, \& Norman, 1998; Dowling \& Pfeffer, 1975), and is fundamental for growth, stability, and organizational survival (Díez-Martín, Prado-Roman, \& Blanco-González, 2013).

Several studies address court legitimacy. Gibson, Caldeira, and Baird (1998) investigated the relationship between the legitimacy of national high courts in different countries and their audiences. They showed that the legitimacy of courts is attached to people's acceptance of their decisions. Nelson and Gibson (2019) investigated the impact of discursive attacks on the legitimacy of the U.S. Supreme Court. The impact of critical discourses depends on the reliability of the sources. Armaly (2020) showed that group loyalty intervenes in the relationship between perceived procedural fairness and social support for the U.S. Supreme Court. When court procedures benefit a group (e.g., partisans), unfairness is seen as acceptable by its members; beneficiaries of judicial impropriety are likely to support the court and not contest its legitimacy.

Research on legitimacy is vast and encompasses efforts to capture its multidimensional structure (Bitektine \& Haack, 2015) or alternative measurements of purpose (Alexiou \& Wiggins, 2019; Vergne, 2011). Research examines what legitimacy is, where it occurs, and how it occurs (Suddaby, Bitektine, \& Haack, 2017). Legitimacy as property focuses on the relationship between the organization and its external environment. On this view, legitimacy is considered to be an organizational attribute that results from the normative expectations of the organization's behavior current in its environment. Legitimacy as process considers legitimacy as a social and political construction influenced by an ongoing interaction between a multiplicity of actors, typically organizations (Suddaby et al., 2017). Legitimacy as perception refers to evaluations or judgments of suitable actions that occur in interactions between organizations (the collective level) and individual actors (the individual level). Actors' judgments and perceptions are the proxy to assess the degree of legitimacy of organizations (Suddaby et al., 2017).

These perspectives on legitimacy (as property, process, and perception) could be useful in court research. In a preliminary outline, the presumed legitimacy is usually attached to courts (Gibson $\&$ Caldeira, 1995) due to the legality inherent to their regular exercise of coercive power. This view stresses legitimacy as an attribute, a capacity, or an asset possessed by courts, that is,

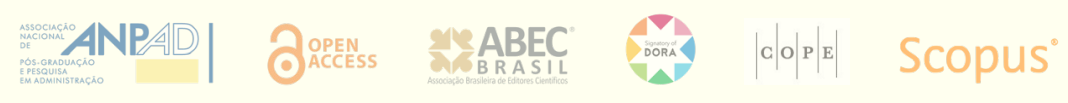


legitimacy as property. It may also be appropriate to treat legitimacy as a process or as perception. Courts are subject to many forms of contestation, over the performance of judges, efficiency criteria, decisions, the appropriateness of jurisdiction, and political bias. Court legitimacy is contentious and is dependent on how stakeholders perceive the suitability of their activities. For their part, courts manage judicial appearances to ensure the acceptability of their judicial power through communicative acts intended to project accessibility and fairness (Bybee \& Narasimhan, 2015; Gillman, 1999). Court legitimacy is contingent on political controversy, purposeful efforts, and mixed judgments of a plurality of social actors.

Courts are perpetually asserting their legal and moral authority (Fallon, 2018). They are subject to social judgments, like other justice organizations, inhabiting the social space populated by multiple agents, including the media, parliament, control bodies, professionals, unions, and civil society organizations (Guimarães et al., 2018). Each exerts its influence on legitimacy, denoting a field-level perspective on legitimacy of justice organizations, or legitimacy as a social and contentious construction in the organizational (or social) field.

In the field where court legitimacy is built, some dimensions deserve attention, such as the motivation for judgments, court design, the public perception of courts, the international scope of some laws, and the implications of court performance for the rule of law (Bybee $\&$ Narasimhan, 2015). Thinking about the social alignment between the courts and their context requires consideration of the performance of the judges, which involves the debate about impartiality and the motivations to judge. However, it also means looking at the social perception of the legal-political dilemma linked to judicial activities, highlighting the impact of these variables on people's belief in judicial authority and the foundations of the rule of law (Bybee \& Narasimhan, 2015). Attention to the social context in which the courts operate should be still greater, as a way to identify interest groups that can guarantee the legitimacy of these organizations and connecting them with binding expectations of governance practices.

\section{DISCUSSION}

Governance and legitimacy intersect in social and organizational dynamics. As governance is understood as a managerial mechanism that enhances and equals social participation, legitimacy is associated with social assessment and perception. By raising the notion of permeable boundaries between legitimacy and governance, it follows that judicial governance can influence the legitimacy of justice organizations in general and of courts in particular. Courts, like other organizations, adopt management and communication policies and strategies that privilege an image of behavior aligned with social expectations.

Our assumption is that courts use governance to reinforce performance, efficiency, and effectiveness and, above all, legitimacy, as well as using judicial symbols. Regarding the relationship between symbols of justice, institutional support for decisions and perception of legitimacy of the U.S. Supreme Court, see Gibson, Lodge, and Woodson (2014). According to these authors, "symbols do not change attitudes; instead, they seem only to activate attitudes that
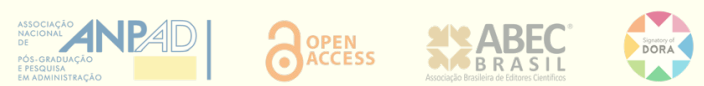
already exist. In some contexts, the symbols of judicial authority may well serve to delegitimize rather than legitimize courts" (Gibson, Lodge, \& Woodson, pp. 860-861).

This adds up to a concern for an adequate (or acceptable) cost-benefit ratio, with impartiality of judgments and transparency. These may increase organizational legitimacy, and it makes sense that stakeholders will accord legitimacy to the courts if they have a positive perception of their governance. To end this section, we set out a general claim and present three propositions (P1 to P3) addressing the relationship between judicial governance and the legitimacy of courts, as shown in Figure 1. Our intention is to provoke insights for future research, which could reinforce or even contradict the assertions that follow.

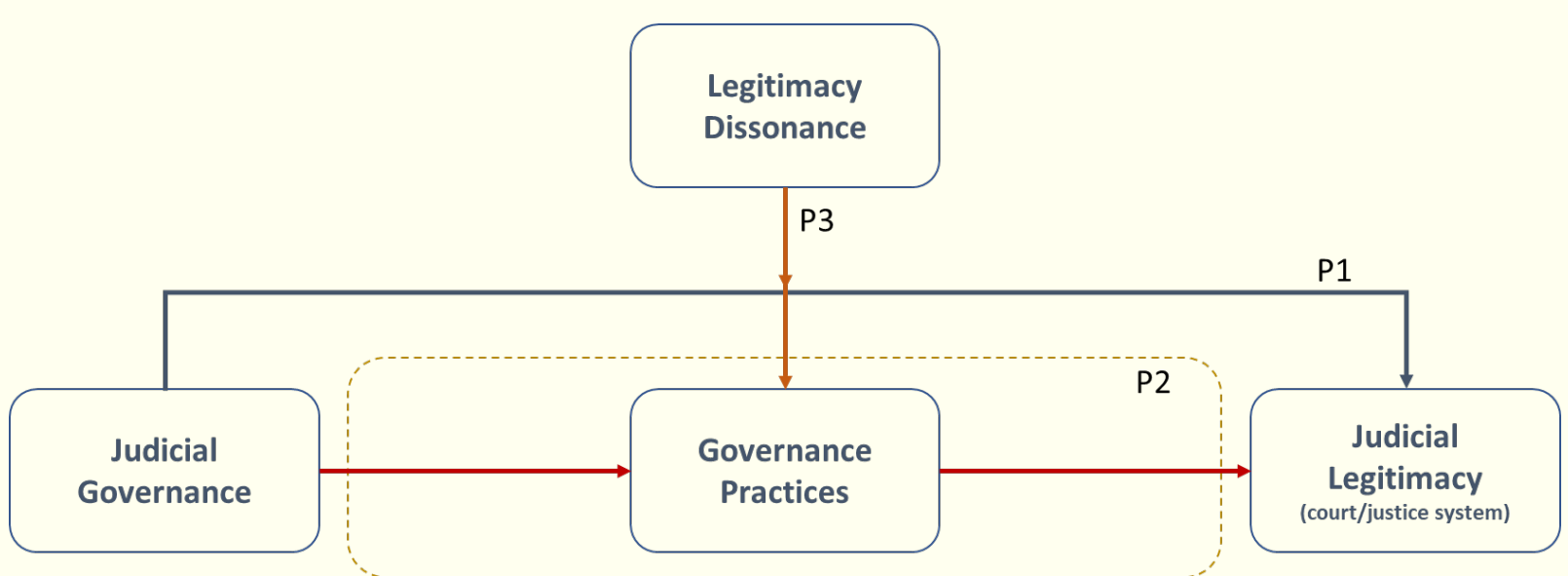

Figure 1. Propositions

The departure point is the premise that the legitimacy of a court is an institutional project involving both the advocacy of a plurality of stakeholders and the conditions of the social context. This project governs the conditions established in the dynamics of a social (or organizational) field. Similarly, the governance of a social system comprises government by a plurality of interdependent actors and socio-institutional arrangements. Therefore, it can be inferred that the governance and institutional legitimacy of courts have recursive relationships, so that they influence each other.

Accordingly, we state that (P1) the better the perception of judicial governance in the social (or organizational) field, the greater the legitimacy of the court. Developing this proposition, it is reasonable to think about three conditions: openness, dissonance, and trustworthiness. As a first extension, the greater the openness of the field to multiple stakeholders interested in judicial governance, the greater the likelihood that governance arrangements positively influence the legitimacy of courts. As a second extension, dissonance arising from ambiguities in the perception of judicial governance negatively influences the legitimacy of courts. And, as a third extension, there is a positive influence of the commitment or conformity of courts to practices and structures of judicial governance on the legitimacy of the justice system as a whole.

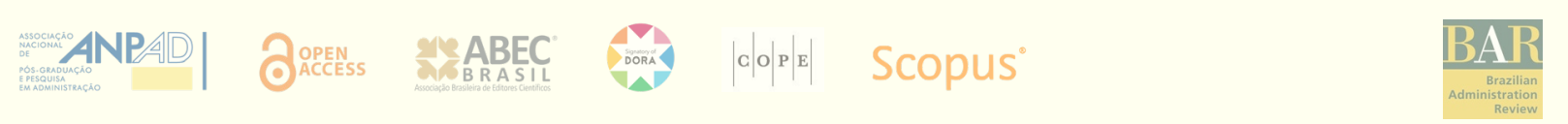


At the organizational level, the reasoning above suggests that practices and structures of judicial governance positively influence the legitimacy of courts, moderated by conditions of the social context. Therefore, (P2) the better the judicial governance in the social (or organizational) field, the greater the likelihood that the courts will adopt such practices and structures and be perceived as legitimate.

In justice systems, the conception and arrangement of judicial governance influence legitimacy of courts. As the conception of appropriate judicial governance becomes more homogeneous in an organizational field, it becomes more likely that the courts adopting such practices and structures will be perceived as legitimate. It is to be expected that structured arrangements of judicial governance, particularly when attached to performance evaluation by public agents, will increase the likelihood of courts adhering to such practices and structures perceived as legitimate.

Going further, since courts are conceived as institutionalized organizations, it is necessary to consider their institutional and organizational facets. The former is related to "a sense of the rightfulness of authority" (Friedman, 2016, p. 193) at the institutional level. In this case, institutional authority and the legal order are the central objects. Conversely, the organizational facet considers the "rulers that occupy the power in a transitory way" (Dogan, 2002, p. 121), i.e., it focuses on organizations, as a transitory form of institution, in the contexts of their ordinary activities and on the social impact resulting from their behavior.

These two layers of ordering and constitution of legitimacy should be noted in research of institutionalized organizations, as is the case of courts and most other justice organizations (Luz, Sousa, \& Guarido, 2019). Fallon (2018) treated these double-edged claims to legitimate authority of courts as Janus-faced. The institutional legitimacy of courts is presumed, which follows from their authority in the institutional framework. However, courts, as organizations, 'activate' institutions, through their practices, processes, and constituents. Thus, the presumption of institutional legitimacy does not necessarily converge on organizational legitimacy. As a premise, we take it that institutional legitimacy and organizational legitimacy mutually reinforce each other.

This legitimacy duality of courts, however, has a puzzling effect for the relationship between governance and legitimacy, which could be perverse. On the one hand, the perception of institutional legitimacy is strongly related to respect for authority, which may induce convergent organizational behavior, i.e., actions oriented to preserve the institutional character of an organization. However, on the other hand, institutional legitimacy may create a sense of overconfidence in authority that supports contradictory organizational behavior, that is, divergent actions that may attempt to present an institutional character based on a presumption of organizational legitimacy.

In such situations, divergent behavior endangers institutional legitimacy through unsettled or erratic practices, even if these practices could contribute to a momentary organizational legitimacy in the short term. In the long term, divergent actions may also undermine organizational 
legitimacy. That could be the case when considering courts and the adoption of practices or structures of judicial governance. Therefore, we state that (P3) the dissonance between the perception of institutional and organizational legitimacy in a social (or organizational) field influences negatively the possibility of adopting governance practices by courts, and, therefore, the effect of judicial governance on the legitimacy of the justice system.

\section{FINAL CONSIDERATIONS}

Courts operate in social contexts like any other organization. This means that although courts are institutionalized organizations, they are not immune to social evaluation, criticisms, and demands. It is central for any thinking about court performance to consider legitimacy seriously and, consequently, the governance issues that are attached on it. Throughout this article, we contend that there are several points of contact between governance and legitimacy of courts, including their recursive relationship. We briefly present three of them. First, the existence of a relationship between judicial governance and the legitimacy of courts. Second, as an extension from the former, judicial governance arrangements and practices can influence the legitimacy of the courts. And third, the eventual dissonance between the facets of legitimacy, institutional and organizational, pervades such a relationship and may influence the adoption of governance arrangements by the courts. As a preliminary conclusion, we intend to blaze a trail, but we have been selective and left aside other possible relationships.

Our arguments draw attention to the fact that courts are a fertile field for studies related to the governance and legitimacy. Treating legitimacy and governance side-by-side (and not theoretically isolated) increases the potential for explaining the actual conditions of courts. By designing research problems of governance and legitimacy in the judicial sphere, a researcher or a practitioner will deal, simultaneously, with the organizational and the institutional facets of the courts. This means that, in addition to any managerial aspect, the institutional contours related to the justice system have material and moral implications. After all, for courts "to be authoritative requires, in essence, a reputation for good decision-making" (Garoupa \& Ginsburg, 2015, p. 2).

This essay is an invitation to pay closer attention to courts as objects of interest to researchers, because of their specific characteristics and their importance in the larger apparatus of the justice system. It is an invitation to recognize that research with courts is research into justice, which means to be concerned with a moral domain of society in which organizations navigate. And, finally, it is an invitation to consider the organizational dimensions, such as legitimacy and governance, in analysis of legal agents. Courts are not a judicial object of interest only to the law or legal sciences. There are managerial and substantive implications of these organizations in society, and organizational and public administration studies must not be reticent in the face of the opportunities to contribute to the increasing knowledge of these issues.

Finally, carrying out empirical research on the governance and legitimacy of courts, as suggested by propositions 1 to 3, may use different methods and techniques. Governance practices and structure of courts can be investigated by conducting case studies, comparative research, or

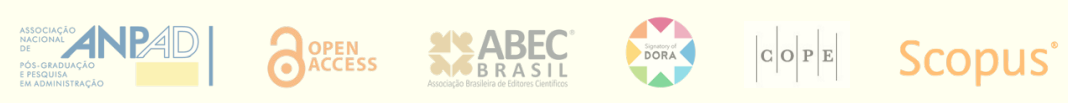


documentary analysis. These are in contrast with surveys of perceptions and interviews with various court stakeholders to describe and test their influence on court legitimacy. Content analysis and speech techniques are useful to analyze texts and news broadcast by different media related to court decisions and behaviors. The analysis of the repercussion on media and different kinds of surveys that monitor procedural practices, obedience to judicial decisions, reputation, or other types of court trustworthiness could be useful for legitimacy research. In this sense, discourse analysis could confirm the dissonance between the organizational and the institutional levels of analysis. There is a great research avenue to be followed in this field, still heavily dominated by texts that focus on legal issues.

\section{ACKNOWLEDGMENTS}

The authors would like to thank the Ministério da Ciência, Tecnologia e Inovação, Conselho Nacional de Desenvolvimento Científico e Tecnológico, for the scholarships granted to the first and second authors and the research project financing CNPq 437295/2018-4.

\section{REFERENCES}

Akutsu, L., \& Guimarães, T. A. (2015). Governança judicial: Proposta de modelo teórico-metodológico. Revista de Administração Pública, 49(4), 937-958. https://doi.org/10.1590/0034-7612116774

Almquist, R., Grossi, G., Helden, G. J. van, \& Reichard, C. (2013). Public sector governance and accountability. Critical Perspectives on Accounting, 24(7-8), 479-487. https://doi.org/10.1016/j.cpa.2012.11.005

Alexiou, K., \& Wiggins, J. (2019). Measuring individual legitimacy perceptions: Scale development and validation. Strategic Organization, 17(4), 470-496. https://doi.org/10.1177/1476127018772862

Armaly, M. T. (2020). Loyalty over fairness: Acceptance of unfair supreme court procedures. Political Research Quarterly. https://doi.org/10.1177/1065912920944470

Berger, J., Ridgeway, C. L., Fisek, M. H., \& Norman, R. Z. (1998). The legitimation and delegitimation of power and prestige orders. American Sociological Review, 63(3), 379-405. https://doi.org/10.2307/2657555

Bitektine, A., \& Haack, P. (2015). The "macro" and the "micro" of legitimacy: Toward a multilevel theory of the legitimacy process. Academy of Management Review, 40(1), 49-75. https://doi.org/10.5465/amr.2013.0318

Brígida, Y. S. S., \& Verbicaro, L. P. (2020). The battle of narratives between the powers: Party hyperfragmentation, judicialization of politics and supremocracy in the Brazilian political-institutional system. Revista de Investigações Constitucionais, 7(1), 137-159. https://doi.org/10.5380/rinc.v7i1.69637

Buta, B. O., Guimarães, T. A., \& Akutsu, L. (2020). Governance in the Brazilian federal public defender's office. International Journal for Court Administration, 11(1), 9. http://doi.org/10.36745/ijca.317

Bybee, K. J., \& Narasimhan. (2015). The legitimacy imperative and the importance of appearances. In A. Sarat \& P. Ewick (Eds.), The handbook of law and society (pp. 118-133). West Sussex: Wiley Blackwell.

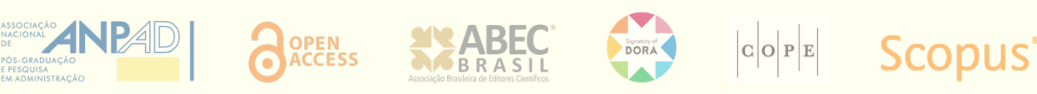


Claessens, S. (2006). Corporate governance and development. World Bank Research Observer, 21(1), 91-122. https://doi.org/10.1093/wbro/lkj004

Ciacchi, A. C. (2014). Judicial governance in private law through the application of fundamental rights. Austrian Law Journal, 1(1), 120-134. Retrieved from https://unipub.uni-graz.at/alj/periodical/titleinfo/308912

Clayton, C. W. (1999). The supreme court and political jurisprudence: New and old institutionalisms. In. C. W. Clyton \& H. Gillman (Eds.), Supreme court decision-making: New institutionalist approaches (pp. 15-41). Chicago: The University of Chicago Press.

Díez-Martín, F., Prado-Roman, C., \& Blanco-González, A. (2013). Beyond legitimacy: Legitimacy types and organizational success. Management Decision, 51(10), 1954-1969. https://doi.org/10.1108/MD-08-2012-0561

Dogan, M. (2002). Conceptions of legitimacy. In Hawkesworth, M. E., \& Kogan, M. (Eds.), Encyclopedia of government and politics (pp. 116-126). London: Routledge.

Dowling, J., \& Pfeffer, J. (1975). Organizational legitimacy: Social values and organizational behavior. Pacific Sociological Review, 18(1), 122-136. https://doi.org/10.2307/1388226

Epstein, L., \& Knight, J. (2004). Courts and judges. In A. Sarat (Ed.), The blackwell companion to law $\mathcal{E}$ society (pp. 170-194). Malden: Blackwell Publishing.

Fallon, R. H. Jr. (2018). Law and legitimacy in the supreme court. Cambridge, MA: Belknap Press.

Friedman, L. W. (2016). Impact: How law affects behavior. Cambridge, MA: Harvard University Press.

Garoupa, N., \& Ginsburg, T. (2015). Judicial reputation: A comparative theory. Chicago: University of Chicago Press.

Gibson, J. L., \& Caldeira, G. A. (1995). The legitimacy of transnational legal institutions: Compliance, support, and the european court of justice. American Journal of Political Science, 39(2), 459-489. https://doi.org/10.2307/2111621

Gibson, J. L., Caldeira, G. A., \& Baird, V. A. (1998). On the legitimacy of national high courts. The American Political Science Review, 92(2), 343-358. http://doi.org/10.2307/2585668

Gibson, J. L., Lodge, M., \& Woodson, B. (2014). Losing, but accepting: Legitimacy, positivity theory, and the simbols of judiciary authority. Law $\mathcal{E}$ Society Review, 48(4), 837-866. https://doi.org/10.1111/lasr.12104

Gillman, H. (1999). The court as an idea, not a building (or a game): Interpretive institutionalism and the analysis of supreme court decision-making. In. C. W. Clyton \& H. Gillman (Eds.), Supreme court decision-making: New institutionalist approaches (pp. 65-87). Chicago: The University of Chicago Press.

Guimarães, T. A., Gomes, A. O., \& Guarido, E. R. Filho. (2018). Administration of justice: An emerging research field. RAUSP Management Journal, 53(3), 476-482. https://doi.org/https://doi.org/10.1108/RAUSP-04-2018010

International Consortium for Court Excellence (2020). The International Framework for Court Excellence (3 ed.). Retrieved from http://www.courtexcellence.com/

Luz, B. B. C., Sousa, M. M., \& Guarido, E. R. Filho. (2019). Legitimacy accounts no debate sobre a reforma dos tribunais de contas brasileiros. Revista de Administração Contemporânea, 23(3), 311-330. https://doi.org/http://doi.org/10.1590/1982-7849rac2019180300

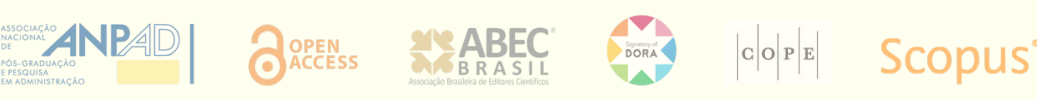


Nelson, M. J., \& Gibson, J. L. (2019). How does hyperpoliticized rhetoric affect the US Supreme court's legitimacy? Journal of Politics, 81(4), 1512-1516. https://doi.org/10.1086/704701

Ramseyer, J. M. (1994). The puzzling (in)dependence of courts: A comparative approach. The Journal of Legal Studies, 23(2), 721-747. Retrieved from https://www.jstor.org/stable/724464

Reinold, T. (2019). When is more more? The proliferation of international courts and their impact on the rule of law in Africa. The International Journal of Human Rights, 23(8), 1337-1355. https://doi.org/10.1080/13642987.2019.1607310

Suchman, M. C. (1995). Managing legitimacy: Strategic and Institutional approaches. The Academy of Management Review, 20(3), 571-610. https://doi.org/10.5465/amr.1995.9508080331

Selznick, P. (1992). The moral commonwealth: Social theory and the promise of community. Berkeley: University of California Press.

Suddaby, R., Bitektine, A., \& Haack, P. (2017). Legitimacy. Academy of Management Annals, 11(1), 451-478. https://doi.org/10.5465/annals.2015.0101

Tavares, J. Q. Neto, \& Barbosa, C. M. (2016). Democratization of justice and governance: Some notes from Brazil. Seqüencia - Legal and Political Studies, 37(72), 41-66. https://doi.org/10.5007/2177-7055.2016v37n72p41

Vergne, J.-P. (2011). Toward a new measure of organizational legitimacy: Method, validation, and illustration. Organizational Research Methods, 14(3), 484-502. https://doi.org/10.1177/1094428109359811

Vieira, O. V. (2017). Ambitious constitutions: Prominent courts. In R. Dixon, \& T. Ginsburg (Eds.), Comparative constitutional law in Latin America (pp. 253-275). Northampton, MA: Edward Elgar Publishing.

\section{Authors' contributions}

$1^{\text {st }}$ author: conceptualization (equal), formal analysis (equal), investigation (equal), methodology (equal), project administration (equal), validation (equal), writing-original draft (equal), writing-review \& editing (equal).

$2^{\text {nd }}$ author: conceptualization (equal), formal analysis (equal), investigation (equal), methodology (equal), resources (equal), validation (equal), writing-original draft (equal), writing-review \& editing (equal).

$3^{\text {rd }}$ author: conceptualization (equal), formal analysis (equal), investigation (equal), methodology (equal), resources (equal), writing-original draft (equal), writing-review \& editing (equal).

\section{Authors}

\section{Tomas Aquino Guimaraes*}

Universidade de Brasília, Faculdade de Administração, Contabilidade Economia, e Gestão Pública

Campus Darcy Ribeiro, Prédio da FACE, Asa Norte, 70910-900, Brasília, DF, Brazil

tomas.aquino.guimaraes@gmail.com

iD https://orcid.org/0000-0001-9261-2407

\section{Edson Ronaldo Guarido Filho}

Universidade Positivo, Programa de Pós-graduação em Administração

R. Prof. Pedro Viriato Parigot de Souza, n. 5300, Campina do Siqueira, 81290-000, Curitiba, PR, Brazil

Universidade Federal do Paraná, Programa de Pós-Graduação em Gestão da Informação

Av. Prefeito Lothário Meissner, n. 632, Jardim Botânico, 81210-170, Curitiba, PR, Brazil
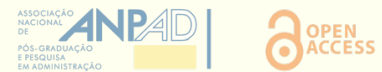
edson.guarido@gmail.com, edson.guarido@up.edu.br

(iD) https://orcid.org/0000-0001-7905-1596

Bruno Batista de Carvalho Luz

Universidade de Brasília, Faculdade de Administração, Contabilidade Economia, e Gestão Pública

Campus Darcy Ribeiro, Prédio da FACE, Asa Norte, 70910-900, Brasília, DF, Brazil

brunobdcl@gmail.com

(iD) https://orcid.org/0000-0002-0066-0995

${ }^{*}$ Corresponding author

Peer review is responsible for acknowledging an article's potential contribution to the frontiers of scholarly knowledge on business or public administration. The authors are the ultimate responsible for the consistency of the theoretical references, the accurate report of empirical data, the personal perspectives, and the use of copyrighted material.

This content was evaluated using the double-blind peer review process. The disclosure of the reviewers' information on the first page is made only after concluding the evaluation process, and with the voluntary consent of the respective reviewers. 